\title{
Chapter 27: \\ The Lake Chad Basin Water Charter: strengths and weaknesses
}

\author{
Emmanuel D. Kam Yogo
}

Lake Chad, the fourth largest lake in Africa after Lakes Victoria, Tanganyika and Nyassa, ${ }^{1}$ poses some challenges to the countries that share its water resources within the context of climate change in the Sahelian zone. ${ }^{2}$ These challenges are manifold and have environmental, economic and social implications. In short, they are challenges to sustainable development.

The drying up of the waters is threating the lake according to some sources ${ }^{3}$, where drastic and alarming developments have occurred over the last fifty years. The combined actions of the climatic factors and the overexploitation of water resources may, in the short term, profoundly jeopardise fishing, livestock farming and agriculture. The preservation of this regional public property calls for an urgent response.

To overcome these challenges, six surrounding and neighbouring states, namely Cameroon, Central African Republic (CAR), Libya, Niger, Nigeria and Chad resolved to strengthen their cooperation to salvage the lake by adopting a binding legal instrument, the Lake Chad Water Charter (LCWC), in April 2012. This Charter is a conventional framework whose overall objective is to ensure that the Lake Chad Basin (LCB) is sustainably developed through the integrated, equitable and concerted management of the shared water resources and the environment of the Basin. The Charter was adopted within a context characterised by several factors such as: the adoption of the African Water Vision 2025 for the equitable and sustainable use of water for socioeconomic development ${ }^{4}$ by the African Union (AU) Extraordinary Summit in March 2000; the adoption of the LCB Vision 2025 in 2000 by the Lake Chad Basin Commission (LCBC); the adoption of a sub-regional Action Plan for Integrated Water Resources Management for West Africa ${ }^{5}$ in Bamako on 16 December 2000; the creation

1 LCBC (2002: 2).

2 Lake Chad is the largest lake in the Sahel zone.

3 See among others, Lake Chad Vision 2025 (LCBC (2002)), and Lemoalle \& Magrin (2014).

4 This LCB Vision 2025 seeks to create a future in which Lake Chad's water resource potential would be fully harnessed to boost and strengthen economic development and social well-being in the region.

5 See Decision A/Dec.12/12/00 of the ECOWAS Heads of State and Government's Summit. 
of the permanent framework for the Coordination and Monitoring of the Integrated Water Resources Management in West Africa (PCMF/IWRM/WA); ${ }^{6}$ the adoption of the water resources policy for West Africa on 5 December $2008^{7}$; and the adoption of the general policy of the Economic Community of Central African States (ECCAS) on Environment and Natural Resources Management in March 2007.

According to its provisions, the Charter "falls in line with the Agreement to establish the Lake Chad Basin Commission as specified and supplemented by the Statute of the Commission signed on 22 May 1964 in Fort Lamy". ${ }^{8}$ It is in this light that its preamble expressly refers to the legal instruments signed on 22 May 1964 in Fort Lamy and its final provisions stipulate that as follows: ${ }^{9}$

The present Water Charter shall be ratified by the State Parties to the Agreement in accordance with constitutional rules and procedures and with the 1964 Convention and Statute and shall come into force within thirty days of the deposit of two-thirds of the Member States' ratified instruments. It shall remain in effect until the term of the Convention for the development of the Lake Chad Basin and the Statute of the Lake Chad Basin Commission of 22 May 1964.

This Charter is, therefore, an agreement which supplements the Fort Lamy Convention of 1964, serving as a protocol to this Convention.

The LCWC does not contain any provision defining its relationship with the 1970 Moundou Agreement on the Extraction of the Waters of River Logone for Agricultural Purposes or the 1977 Enugu Agreement on Common Wildlife Regulations. Since the issues handled by these two agreements have largely been addressed by the LCWC for the $\mathrm{LCB}^{10}$, it suffices to simply note that they will tacitly go extinct when the Charter enters into force in accordance with the provisions of Article 59(1) of the Vienna Convention on the Law of Treaties. ${ }^{11}$

As mentioned above, the overall objective of the LCWC is to ensure that the LCB is sustainably developed, through the integrated, equitable and concerted management of its shared water resources and environment. ${ }^{12}$ This overall objective is supplemented by eleven specific objectives: the quantitative management of surface water resources; the qualitative management of wetlands; the management of groundwater

6 See Decision A/Dec.5/12/01.

7 See Additional Acts A/SA.5/12/08 of ECOWAS.

8 See Article 6 of the LCWC.

9 See Article 95 of the LCWC.

10 Articles 14 to 19 of the LCWC deals with the extraction of water (in the 1970 Moundou Agreement), while Articles 28 to 32 borders of the protection of biodiversity (in the Enugu Agreement).

11 According to Article 59(1) of the Vienna Convention on the law of treaties, "a treaty shall be considered as having come to an end where all its contracting parties later sign a treaty on the same subject and: (a) if it appears from the later treaty or if it is otherwise established that according to the intention of the parties the matter must be governed by that treaty; or (b) If the provisions of the later treaty are incompatible with those of the earlier treaty to such an extent that it is impossible to apply the two treaties at the same time". In the same vein, see Daillier et al. (2009: 338-339).

12 See Article 3 of the LCWC. 
with the determination of principles and rules for the management of transboundary groundwater; the preservation of ecosystems and their biodiversity; the management of navigation; the determination of navigation principles and rules on the lake and its contributors; and, in particular, the assurance of freedom of navigation for the states of the Basin; the definition of procedures for the examination and approval of new projects that could have a significant quantitative or qualitative impact on the water resources; the dedication of common works and works of common interest; as well as the management of projects for the benefit of the Commission; the determination of responsibilities of national and regional authorities; the sharing of data and information and the participation of the public; the prevention of conflicts, and the assurance of the effective prevention and resolution of interstate conflicts associated with the management of shared water resources; and improvement of the socio-economic conditions of the populations. ${ }^{13}$

The Charter is guided by eighteen further general principles, which include: the sustainable development principle; the principle of prevention; the abstractor-pays principle; the polluter-pays principle; the costs and benefits sharing principle; the principle of subsidiarity; the principle of information and participation; the precautionary principle; the principle of solidarity; the principle of cooperation; the principle of partnership; the principle of equity; the principle of hydrographic sub-basin management; the principle of gender consideration; the principle of accountability; the principle of good governance for the environment; the principle of complementarity; and the principle of progressivity. ${ }^{14}$

By establishing the LCB water statute, the LCWC specifies that the lake, rivers and aquifers and aquatic ecosystems contained in the lake's watershed are declared international waters. These waters thus constitute the common heritage of the LCB member states. ${ }^{15}$ It is therefore appropriate to consider whether there is a convergence or divergence between the LCWC and other international legal instruments on water, including the Convention on Wetlands of International Importance, particularly as Waterfowl Habitat of 2 February 1971; the Convention on the Protection and Use of Transboundary Watercourses and International Lakes of 17 March 1992; and the Convention on the Law of the Use of International Watercourses for Purposes other than Navigation of 21 May 1997.

Furthermore, questions arise about the legal relationship between the LCWC and other Water Charters in Africa, in particular, the Niger Water Charter and the Senegal River Charter. What is the relationship between national laws of member states on water management and the LCWC? Do these need to be consistent? Will the LCWC 
be a solid legal base for member states to achieve the Sustainable Development Goals (SDGs) relating to water?

While finding the answers to these questions, it is important to analyse how universal principles on international water management are enshrined in the LCWC, and to examine the environmental context of its multi-sectoral character.

2 Universal principles on the management of international waters

The international law relevant to freshwater resources outlines a number of principles enshrined in several universally recognised instruments. ${ }^{16}$

\subsection{Integrated management of water resources}

Integrated management of water resources is generally defined as a process that promotes the coordinated and rational development and management of water, land and related resources. This is to be done to maximise, in an equitable manner, economic and social well-being without undermining the sustainability of vital ecosystems. This definition is enshrined both in the LCWC $^{17}$ and Article 1 of the Niger Basin Water Charter. The Senegal River Water Charter also addresses integrated water resources management taking into account a certain number of parameters. ${ }^{18}$ Moreover, according to Agenda $21^{19}$

integrated water resources management is based on the idea that water is an integral part of the ecosystem and constitutes a natural resource and a social and economic good whose quantity and quality determine its distribution. For this purpose, water resources must be protected considering the functioning of aquatic ecosystems and the sustainability of the resource in order to meet or reconcile water requirements with human activities.

Integrated water resources management is also enshrined in the African Convention on the Conservation of Nature and Natural Resources, essentially concerning the fair and reasonable use of water resources and the rationalisation of extraction. However, in explicit terms, national laws of states party to the LCWC do not include integrated water management.

16 In this regard, see Boisson de Chazournes \& Tignino (2013); and Boisson de Chazournes \& Tignino (2011: 245-261).

17 See Article 2 of the LCWC.

18 Article 5(2) of the Senegal River Water Charter.

19 See Chapter 18 of Agenda 21. 


\subsubsection{Fair and rational use of water resources}

The LCWC provides that the state parties shall use the surface water resources and Basin aquifers within their national boundaries in a fair and rational manner in order to ensure optimal and sustainable benefits consistent with the legitimate interests of each Basin state, and with the aim to protect Lake Chad and its watercourses, aquifers and aquatic ecosystems. For ground and surface water, the equitable and rational use is based on the commitment of state parties to respect defined limits. ${ }^{20}$

Since an uncontrolled increase in the extraction of water resources could have significant impacts and lead to a serious reduction in the volume and surface area of the lake, state parties undertake to respect the total volume of water consumed from the lake's inlets, their alluvial groundwater, the lake's aquifers or from the lake itself and should not exceed predefined limits. ${ }^{21}$ The LCBC arbitrates the equitable sharing among the state parties by means of providing authorisations for extraction..$^{22}$ In addition, state parties undertake to limit groundwater extraction to adapt to the capacity of the transboundary aquifers or aquifer systems of the LCB in order to ensure their sustainable exploitation. States must ensure that they comply with the environmental flows projected at key points in the LCB to conserve aquatic ecosystems and the services they provide. Such compliance may require limiting water extraction by defining maximum volumes.

While enforcing the obligation of fair and sustainable use, states must also take into account the following factors which, for the most part, are also enshrined in the United Nations Convention on the Uses of International Watercourses for Purposes other than Navigation, which was adopted in 1997 and came into force in 2014:23

- geographical, hydrographical, hydrological, hydrogeological, climatic, ecological and other natural factors;

- economic and social needs of states parties;

- needs of ecosystems, especially wetlands, and in particular the maintenance of environmental flows to maintain the services provided by ecosystems;

- population relying on Lake Chad or the rivers, aquifers and aquatic ecosystems contained in its watershed;

- $\quad$ effects of the use by a state of Lake Chad or its watershed rivers, aquifers and aquatic ecosystems on other Basin states;

- current and potential uses of Lake Chad and its watershed rivers, aquifers and aquatic ecosystems, including the cumulative impact of extraction and pollution;

20 Articles 11 and 12 of the LCWC

21 See Appendix 2 of the LCWC.

22 See Article 17 of the LCWC.

23 Cf. Article 6 of this Convention. 
- conservation, protection, enhancement and economy in the use of water resources of Lake Chad or its watershed rivers, aquifers and aquatic ecosystems and the costs of measures taken to this effect;

- other options that may substitute a particular current or envisaged use;

- planning for the development of the LCB;

- $\quad$ sharing of water resources among all users, aquatic systems and associated ecosystems;

- availability of other resources and the cost of a possible substitution;

- avoidance of wasting waters of the LCB;

- the principle of compensating the state that is obliged to forego an activity in order to reconcile divergent uses;

- avoidance of harm likely to be caused by new or extended use;

- recognition of rights of the populations to the LCB's waters;

- the endorheic nature of the lake, which increases the risks of pollution accumulation and cumulative impact on the lake's water levels, water extraction, alluvial aquifers of its inlets and the lake's aquifers;

- inter-basin water transfers that may affect the hydrology and water resources of the lake and associated watercourses; and

- the effects of climate variations and change.

The aforementioned factors equally need to be taken into consideration when it comes to the fulfilment of states' obligations under the 1971 Ramsar Convention on Wetlands of International Importance especially as Waterfowl Habitat. ${ }^{24}$

\subsubsection{Rationalisation of water extraction}

According to the LCWC, no use of Lake Chad's waters, surface water or groundwater of its watershed, can be considered as a priority in relation to other uses. However, in the event of a conflict between uses, satisfying the basic human needs of the population must be given priority. A state party may not reserve future use of the water resources of the LCB to the detriment of a current fair and rational use since future needs, even if they are to be taken into account in the context of sustainable development (consideration of future generations), should not threaten or relegate current needs. To deprive present generations of water resources would mean to condemn them to death, as water is life.

For the purpose of rationalisation, water extraction from Lake Chad or the surface or ground waters of its watershed, is subject to either an extraction authorisation or a prior declaration in accordance with a predetermined nomenclature. Extraction 
authorisations issued by states to public or private individuals or corporate entities must be subject to the approval of the LCBC and must take into account the availability of water resources and the various uses for which they are intended. The authorisations must also meet the environmental protection and sustainable development requirements prescribed under the LCWC. ${ }^{25}$

Individual and corporate bodies (either private or public), who are granted extraction authorisations have to pay an annual tax as a contribution to the costs of mobilising water resources to meet socio-economic and environmental needs. Such tax is collected by the national authorities in accordance with their financial rules and procedures. The amount and rate of distribution between the state parties and the LCBC are determined by the latter. ${ }^{26}$

Finally, states parties may enter into bilateral or multilateral water-sharing agreements, provided that they comply with the LCWC and that the LCBC is informed of their content. Thus, if for instance Cameroon and Chad desire to sustain the 1970 Moundou Agreement on River Logone Water Extraction for Agricultural Purposes, they will need to renegotiate it in order to ensure that it complies with the provisions of the LCWC. Where state parties use transboundary aquifers or aquifer systems that extend beyond the territorial scope of the LCWC as defined in Article 5, they will have to take the necessary measures to protect the legitimate interests of aquifer states that are not members of the Commission. ${ }^{27}$

\subsection{Cooperation between lakeside states}

Cooperation between states bordering Lake Chad concerns, inter alia, notification, consultation and approval of projects and works. This cooperation is facilitated by the creation of appropriate institutions.

The Charter requires state parties to notify all other Basin states and the LCBC of any natural or man-made disasters affecting the lake or the watercourses, aquifers and aquatic ecosystems of the Basin watershed originating from their territory. Such notification shall provide an indication of the characteristics of the emergency situation, the measures taken by the state party to mitigate its consequences on its territory and any other information that may enable other Basin member states to take the necessary measures to prevent or reduce the consequences of the emergency situation on their territory.

In order to prevent and mitigate emergency situations, member states shall jointly develop and implement contingency and adaptation plans in collaboration with the 
LCBC in order to eliminate or reduce harm that may be caused to populations, the environment and the Basin's water resources. ${ }^{28}$

The Basin states shall provide mutual assistance where emergencies arise. Assistance to affected states shall be provided in accordance with the terms and conditions previously agreed upon by the state parties and in accordance with the principles and rules of international law.

Any state party that causes significant harm to another state party, notwithstanding the obligation to prevent transboundary harm, shall immediately enter into consultation with the state affected by that harm in order to eliminate or mitigate the consequences of such harm as soon as possible. State parties shall accordingly consult each other for compensation for significant transboundary harm caused to other state parties by the use of the lake or the surface or ground waters of its watershed within their respective boundaries. Compensation for transboundary damage shall be determined in accordance with international law. Where a state party intends to undertake projects likely to have significant adverse effects beyond its boundaries and where such projects are included in the nomenclature of the proposed compulsory notification measures, it shall notify the other member states through the LCBC. Written notification shall be made in a timely manner and shall include all necessary information and data to enable the LCBC and the recipient states to assess potential transboundary adverse effects of the proposed measure. ${ }^{29}$ Upon receipt of the notification, the LCBC shall communicate with state parties in writing as soon as possible, and at the latest one month after receipt of the complete file. The states to which the notification is addressed shall have a period of four months from the date of receipt of the notification to comment on the proposed measures and to communicate their response to the LCBC, which shall in turn inform all state parties thereof. If, at the end of this period, no reaction is received from a state to which the notification had been addressed, it constitutes a tacit consent to the implementation of the proposed measure. ${ }^{30}$ Upon expiry of the response time granted to states, the LCBC shall, for the purpose of examining and issuing its opinion, submit to the Committee of Experts on Water Resources and the Committee on Environment, Science and Planning, the notification of the proposed measure along with the observations of state parties. The Committee shall then review the notification with due consideration of all relevant factors and consequences for the Lake Chad Basin. ${ }^{31}$ The Committee may draw on the expertise of outside persons in the field of water and environment, and may provide reasoned expert advice. ${ }^{32}$

In the wider context of cooperation, states parties may undertake to construct common works or works of common interest, and may also agree to declare as common 
works or works of common interest those already existing in the Basin. ${ }^{33}$ The LCBC coordinates the management of any Basin water structures with transboundary impacts. This coordination includes tactical management, seasonal planning, as well as short-term and real-time operational management.

The LCWC provides for a number of institutions that facilitate cooperation among member states. These institutions differ in their political, administrative or technical nature.

Political institutions include the Summit of Heads of State and Government and the Council of Ministers and the Parliamentary Regional Committee. As an administrative institution, there is the Executive Secretariat. Technical bodies include the Technical Committee; the Committee of Experts on Water Resources; the Committee on the Environment, Science and Planning; National Agencies of the LCBC; and the Partners' Forum on the Sustainable Development of LCB. ${ }^{34}$

During the last Summit of the Heads of State of the LCBC member countries, which was held in February and March 2018, the project to transfer water from Ubangi Chari to Lake Chad witnessed tremendous progress. The implementation of this project will strengthen cooperation among state parties to the Charter. Regrettable, however, is the fact that the LCWC does not provide for a specific framework that brings together all the water ministers of the various member countries. In some countries, such as Cameroon, the Minister of the Economy is the official interlocutor to the LCBC, while the Minister of Water often plays no role in the context of LCB cooperation. As a result, ministers from the Basin member states who are not competent on water matters attend the ministerial meetings. In addition, the fact that states belong to different regional blocks also hampers the cooperation efforts between the parties to the LCBC. This is to name but a few weaknesses of the LCWC for the LCB, where integrated water management is so critical.

The LCWC contains ambitious provisions relating to environmental protection that provide for environmental impact assessments, ${ }^{35}$ environmental audits, ${ }^{36}$ strategic environmental assessments ${ }^{37}$ and the harmonisation of the environmental assessment laws $^{38}$ of the various member states. In more detail, the LCWC contains important 
provisions in the fight against pollution, the protection of biological diversity and fisheries products, and for the management of risks and natural disasters.

\subsection{The fight against pollution}

To prevent, control or reduce pollution, LCB member states undertake to:

- control and combat any action likely to significantly modify the characteristics of the lake or the watercourses, aquifers and aquatic ecosystems of its watershed zone, their sanitary and physio-chemical state, biological characteristics and the environment in general;

- take all necessary steps to preserve the quality of the groundwater of the Basin in order to ensure sustainable exploitation; and

- combat pollution at the source.

As general pollution control measures, member states and the LCBC shall identify water quality objectives and criteria, establish techniques and practices for combating pollution from stationary and diffuse sources, and draw up lists of substances and concentrations that should not be introduced into the waters of the Basin or should be limited or subjected to research and monitoring. They shall further preserve the aquatic environments that contribute to the conservation of the good quality of water. Each state shall, in addition, inform the LCBC of any polluting emissions from its territory, that are likely to have significant harmful effects on water resources and/or the environment in other state party's territory.

The LCBC, together with the state parties, establishes standards of pollutants discharge in accordance with the objectives of the LCWC. However, it is important to note that any discharge of radioactive pollutants is forbidden in the Basin.

Any polluting discharge into Lake Chad and the surface or ground waters of its hydrographic basin is subject to either a discharge permit or a prior declaration in accordance with prescribed pollution standards. The nomenclature of samples subject to authorisation or declaration is determined by the LCBC. Any pollutant discharge likely to endanger public health and safety or likely to pose a threat to the biodiversity of the Basin, shall be subject to authorisation. ${ }^{39}$ Discharge authorisations are issued by each member state after the approval of the LCBC, which must make its decision within three months. Beyond this deadline, the state party may proceed without the opinion of the LCBC. ${ }^{40}$ In any event, authorisations to discharge must take account of the nature of the pollutants, and the hydrological and ecological characteristics of the receiving environment. Furthermore, all parties agree to set up, through the LCBC, a regional 
system to regulatory monitor water quality in the Basin. The data produced shall thereafter be integrated into a regional database.

Public or private individuals or corporate entities in possession of any discharge authorisation are subject to payment of an annual tax as a contribution to the cost of pollution prevention, control and abatement measures under taken by public authorities. This is a means of implementing the polluter pays principle as enshrined in the LCWC, which provides that "the cost of pollution prevention, control and abatement measures shall be entirely or partially covered by the polluter". ${ }^{41}$

\subsection{Protection of biodiversity and fisheries products}

Member states of the LCWC undertake to regularly identify, make inventory of and monitor the biodiversity of aquatic ecosystems of the Basin and to take appropriate measures for their conservation by paying particular attention to endangered species. In addition, members pledge to exploit biological resources of the Basin only in a sustainable manner. ${ }^{42}$ These commitments make the LCWC consistent with the universal legal instruments such as the United Nations Convention on Biological Diversity (CBD). The CBD aims to protect biological diversity, to promote the sustainable use of its components, to foster the fair and equitable sharing of the benefits accruing from the exploitation of the genetic resources, including through adequate access to genetic resources and adequate transfer of relevant technologies. It takes into account all rights over the aforementioned resources and technologies, and appropriate funding. ${ }^{43}$

Member states have to take all necessary measures to monitor the introduction of alien or new invasive aquatic fauna or flora that may adversely affect the Basin's ecosystems. Such measures shall contribute to the conservation of the LCB as a natural heritage. It should be recalled here, that the 1972 Convention of the United Nations Educational, Scientific and Cultural Organization (UNESCO) concerning the Protection of World Cultural and Natural Heritage, defines natural heritage as the geological and physiographic formations and strictly delineated areas constituting the habitat of endangered animal and plant species, which are of outstanding universal value from the point of view of science or conservation. ${ }^{44}$ Synergies also enfold between the implementation of the provisions of the African Convention on Nature and Natural Resources ${ }^{45}$ and the LCWC. It is important to note, however, that the commitments made by member states with regard to biological diversity under the LCWC go beyond the 1977 Enugu Agreement and make the latter virtually obsolete.

41 See Article 7(d) of the LCWC.

42 See Article 28 of the LCWC.

43 See Article 1 of the Convention on Biological Diversity.

44 See Article 2 of the 1972 UNESCO Convention.

45 In particular, Article 12 of this Convention. 
Member states shall also take appropriate measures to ensure sustainable exploitation of fishery resources in the Basin. In this regard, they are called to establish areas for the conservation of fishery resources by creating fish reserves and by prohibiting areas of the aquatic domain in order to maintain spawning stocks. Harmonisation of national fisheries legislation is being envisaged at the level of the $\mathrm{LCWC},{ }^{46}$ despite the difficult nature of such an exercise. This is comparable, for instance, with the experience of the Central African Forest Commission (COMIFAC) in the forest sector where the harmonisation of national forest legislation remains unattained after more than a decade.

\subsection{Risk and disaster management}

A natural disaster is defined in the $\mathrm{LCWC}$ as: ${ }^{47}$

.... a serious disruption of the functioning of society, which poses a real and widespread threat to life, health, property or the environment, whether arising from an accident, nature, or human activity, whether developing suddenly or as a result of long-term processes, but excluding armed conflict.

Member states of the LCWC are particularly vulnerable to disasters such as floods, earthquakes and tremors, lake lethal gases, volcanic eruptions, rock avalanches, landslides, bushfires and droughts. It is in this light that relevant provisions of the LCWC have expressly identified risk and disaster management as a key area for cooperation between the member states. The LCWC thus stipulates that member states and the LCBC undertake to adopt measures necessary to combat situations that are damaging to the ecosystems of the LCB, such as erosion, riverbank degradations, floods, droughts, desertification and deforestation, ${ }^{48}$ and to reduce the deterioration of lands. Furthermore, member states undertake to adopt measures necessary to protect, preserve, sustainably use and rehabilitate the Basin plant cover. Each member state, insofar as it is predisposed to flooding by the lake or its tributaries, or to the extent that its geographical position enables it to predict such risk, is required to:

- identify or map the hazard, vulnerability and risk areas potentially subject to flooding on its territory;

- identify, in a database, remarkable floods and feedbacks on experiences in the management of these occurrences;

- develop and maintain a forecasting and early warning system including rainfall and hydrometric stations; and

46 See Article 34 of the LCWC.

47 See Article 3 of the model act for the facilitation and regulation of international disaster relief and initial recovery assistance.

48 See Article 29 of the LCWC. 
- prepare safeguarding plans to define actions to be taken in the event of an alarm or a crisis situation.

Furthermore, during current and future situations of flooding, member states are required to: ${ }^{49}$

- manage hydraulic structures so as to reduce the risk or not to increase it;

- put in place any action likely to alert the population as soon as possible and to minimise the impact of flooding; and

- inform, each year, the population living on the banks of the lake about the maximum level that can be reached on the lake coast, based on the analysis of flood hydrographs of the Chari and Logone rivers.

Member states also undertake to define objective indicators that enable them to qualify and anticipate particularly severe low water conditions that render it impossible to respect the flows defined in Article 12, while abstracting water from the duly authorised flows. They also undertake to define the measures to be taken in such situations by including, among others: ${ }^{50}$

- economical management of demand through water-saving measures and regular checking of abstraction flow rates;

- defining the rules to classify in order of priority the recipients of the water available in the regulation reservoirs and encouraging a careful management of these stocks; and

- actions to reserve the resource available for the distribution of drinking water. In short, the LCWC commits member states to take specific measures to prevent severe low water levels and drought. It is in this perspective that during the fifteenth Summit of Heads of State of the LCBC held in February 2018, the question of transferring water from the Ubangi-Chari River to Lake Chad was addressed. What is regrettable, however, is that the LCWC does not provide for a direct connection with the United Nations Convention to Combat Desertification (UNCCD) by offering the possibility for the LCBC to effectively subscribe to this UN instrument. Such coupling could effectively lead to a greening of the entire LCB region.

\section{The multi-sectoral nature of the Lake Chad Water Charter}

The LCWC targets several sectors that are important in achieving its ambitious objectives. Some of the sectors addressed include human rights, peace and economic sectors, which make these ambitions consistent with the following Sustainable Development Goals, in particular, Goals No. 1, No. 2, No. 3, No. 6 and No. 15. 


\subsection{Human rights considerations}

The LCWC recognises the right of the people to water and sanitation as a fundamental right necessary for their dignity. Member states must therefore take the necessary normative, institutional and operational measures to ensure the realisation of this right.

The right to information about the environment is also guaranteed. State parties, through public consultation, must ensure that information concerning the state of water resources, the environment and the measures taken or envisaged concerning the Basin are accessible to the population so that they can effectively participate in consultations organised by public authorities as part of the decision-making process in water resources and environmental protection. They must ensure that the people have effective access to administrative and judicial remedies for the implementation of this right. The LCBC establishes a participation plan, which defines the conditions for public information and participation in the management of the Basin's water resources.

State parties undertake to pay particular attention to the needs of women, youth and vulnerable groups in the management of water resources and the environment of the Basin. Cultural rights are also taken into account as member states acknowledge the importance of local techniques and know-how applied in environmental protection, which are consistent with the sustainable management of the Basin's natural resources. They also assure that the role of traditional and customary leaders regarding the protection of the environment and water resources is taken into full consideration. They encourage, in particular, the traditional system of sharing water in the Basin taking necessary measures to ensure the protection of local knowledge, and a greater involvement of customary and traditional authorities in the management of water and the protection of the environment. This provision is similar to that of the African Convention on the Conservation of Nature and Natural Resources, which requires states to take legislative measures in order to ensure that the traditional and intellectual property rights of local communities are respected and that access to and use of traditional knowledge are subject to prior and informed consent of the concerned communities. ${ }^{51}$

The economic rights of livestock farmers are also recognised. The LCWC provides that member states must acknowledge the right of herders in the Basin to exploit pastoral resources, including plant, water and mineral resources to feed their livestock. Member states must also create the conditions necessary for these pastoral rights to be enjoyed in accordance with national laws.

State parties acknowledge and undertake to ensure the right of the local population to participate equitably in the sharing of benefits resulting in particular from the commercial and industrial exploitation of the genetic resources of the Basin in accordance with relevant international agreements. One instrument worth specific mention in this regard is the Nagoya Protocol to the Convention on Biodiversity concerning the 
Access to Genetic Resources and the Fair and Equitable Sharing of Benefits Arising from their Utilisation. This Protocol has been ratified by Cameroon and other member states of the LCB. At the same time, LCB member states adopted national strategies on access to genetic resources and the fair and equitable sharing of benefits arising from their utilisation.

Moreover, member states acknowledge the rights of civil society organisations and legally established grassroots organisations to defend their collective interests in court in matters concerning the environment and water resources. ${ }^{52}$ In order to enable the local population to effectively enjoy their rights, the LCBC advocates for the creation of civil society organisations within the Basin area, with national and local agencies. Civil society organisations and grassroots community organisations that contribute to the sustainable management of the Basin shall receive technical and financial support. All these ambitions of the LCWC are equally consistent with the African Convention on the Conservation of Nature and Natural Resources, which stipulates that its member states must guarantee the rights of the people to participate in decision-making, to have access to information on environment and to have free access to justice in environmental matters. ${ }^{53}$

\subsection{The need to preserve peace around the Basin}

The risks of inter-community and inter-state conflicts in the Basin are a concern to states bordering Lake Chad. Thus, the LCWC has enshrined the principle of solidarity, by which sub-regional inter-state cooperation for the sustainable management of the Basin is founded on the idea that Lake Chad and the watercourses, aquifers and aquatic ecosystems found in its hydrographic basin constitute an asset of "common heritage". In this light, state parties undertake to preserve such assets in the interest of all states to promote peace and development in the sub-region by ensuring political and social cohesion in the Basin, and by supporting the populations and most underprivileged areas in order to gradually eradicate inequalities. State parties agree to peacefully settle any dispute arising from the application or interpretation of the LCWC, in accordance with the United Nations Charter, the Constitutive Act of the African Union and the Declaration on Principles of International Law concerning Friendly Relations and Cooperation among states.

State boundary disputes in the Lake Chad area are on the increase. ${ }^{54}$ Thus, in the LCB, "boundaries only exist in the minds of the states and not in the mind of the

52 See Article 77 of the LCWC.

53 See Article 16 of the African Convention on the Conservation of Nature and Natural Resources.

54 Sourna Loumtouang (2014: 1-2). 
population who, in their quest for survival, violate them unknowingly". ${ }^{55}$ The LCWC has so far failed to provide clear solutions regarding existing border disputes. This is another shortcoming of this legal instrument. We can only assume that in the event of any border dispute erupting between member states within the Basin, the principle of the intangibility of borders inherited from colonisation shall apply. Based on this principle, effective reference has been made in the preamble of the LCWC to the Constitutive Act of the African Union and the United Nations Charter on the Management of Border Disputes. During the settlement of the border dispute between Cameroon and Nigeria, the two member states of the LCB heavily depended on this principle. In the Statement of the Federal Government of Nigeria concerning the ruling of the International Court of Justice (ICJ) regarding the LCB, it stipulates that: ${ }^{56}$

The Nigerian Local Government Area in the North-East has traditionally provided administrative services and infrastructure for the 60,000 or so Nigerians living in this area. Notwithstanding, the Court ruled that the colonial boundaries are to be respected.

In the event of a dispute between states parties over the interpretation or application of the LCWC, the parties concerned shall seek a solution through direct negotiation. Such negotiation shall be conducted in a climate of good faith with a willingness to reach an agreement. Where state parties fail to reach an agreement through negotiation, they shall resort to the good offices or the arbitration of the LCBC in order to reach a solution acceptable to both parties. Where the LCBC fails to settle the dispute, one of the state parties may seek the good offices or the arbitration of competent regional or subregional organisations. Where all the above dispute settlement mechanisms prove unsuccessful, state parties shall resort to mediation or legal settlement by the ICJ. Where this occurs, state parties are expected for the duration of the dispute settlement period, to abstain from any act that is likely to escalate the situation in the interest of a peaceful and final settlement of the dispute.

A main weakness of the LCWC is its silence on the fight against terrorism. Despite this fact, member states are increasingly organising themselves to face the scourge. Thus, during the fourteenth Ordinary Summit of Heads of State and Government of the LCBC held in Ndjamena in April 2012, a decision was reached to launch a Multinational Joint Task Force made up of troops from Cameroon, Chad, Niger and Nigeria. This initiative has been endorsed by the United Nations Security Council and the African Union Peace and Security Council.

55 Ibid: 11.

56 Olinga (2009: 166). 


\subsection{Consideration of economic activities}

The fight against poverty is a major concern for the states bordering Lake Chad. Some of the specific objectives of the LCWC include to improve of the socio-economic conditions of the population to foster food security in order to guarantee a steady and secured supply of foodstuffs to the population. It also recognises the need to fight poverty and improve the living conditions of the population in order to better the living standards, while ensuring peaceful conditions for collaboration among member states. The LCWC also deals with the principle of complementarity by which member states can, within the framework of regional integration, make the most of complementarities in their economies based on their respective current or potential comparative advantages within the LCBC. Satisfying economic needs of the population is repeatedly reiterated in the LCWC. ${ }^{57}$

\section{Conclusion}

The LCWC aims to harmonise member states' laws. It thus provides for the harmonisation of laws and institutions on fisheries, ${ }^{58}$ the harmonisation of laws on environmental assessment, ${ }^{59}$ the harmonisation of fisheries, environment, water and navigation policing ${ }^{60}$ and the harmonisation of data collection and processing methods. ${ }^{61}$ Harmonisation of laws, as a method of legal integration, should, however, not be mistaken for unification and uniformity. Harmonisation refers to "a simple reconciliation between two or more legal systems" 62 in order to put an end to certain existing contradictions and differences. The LCWC straddles the West Africa sub-regional bloc (Nigeria and Niger), the Central Africa sub-regional bloc (Cameroon, Chad and Central African Republic) and to a certain extent the Maghreb sub-regional bloc (because of Libya). Conducting a harmonisation process in such a complex regional context is extremely difficult. This may constitute another weakness of the LCWC. The geographical location of the LCB, which is shared between several sub-regional blocs (ECOWAS, ECCAS and Maghreb) makes the harmonisation efforts recommended by the LCWC challenging. These challenges to the harmonisation of legislation between countries of the LCB are all the more conceivable in Central Africa in another subregional organisation, the Central African Forests Commission (COMIFAC). 
COMIFAC has to date failed to successfully harmonise forestry legislation. ${ }^{63}$ As a harmonisation organisation, COMIFAC did not achieve the expected results in spite of the fact that all its members belong to the same regional bloc, the Economic Community of Central African States (ECCAS). If an organisation which enjoys a unique regional and institutional framework such as COMIFAC fails to achieve its harmonisation objectives, how can one expect any better from an organisation that spans across different sub-regions?

Persistent differences between legal and regulatory frameworks of member states, some of which have not yet internalised the integrated management of water resources, are also a flaw in the LCWC. Added to this are the uncertainties about stable bilateral relations between certain LCB member states. These uncertainties have been observed in the relations between Chad and Nigeria, Chad and the CAR, Cameroon and Nigeria and between post-Kaddafi Libya and other member states. At the judicial level, the LCWC totally disregards other African judicial bodies and refers member states directly to the ICJ when seeking the legal settlement of a dispute. This is another weakness of an instrument adopted in 2012, at a time when Africa was already striving to boost African judicial bodies.

\section{References}

Boisson de Chazournes, L \& M Tignino (2011) “Gestion internationale de l'eau et développement du droit international" in Le Prestre (ed.) Vingt ans après : Rio et l'avant-goût de l'avenir 245-261.

Boisson de Chazournes, L \& M Tignino (2013) Droit international et eau douce.

Cornu, G (2000) Vocabulaire juridique.

Daillier, P, M Forteau, NQ Dinh \& A Pellet (2009) Droit international public.

LCBC / Lake Chad Basin Commission (2002) Gestion intégrée de bassin fluvial, les défis du bassin du lac Tchad: Vision 2025.

Lemoalle, J \& G Magrin (2014) Le développement du lac Tchad: Situation actuelle et futurs possibles. Olinga, AD (2009) L'Accord de Greentree du 12 juin 2006 relatif à la presqu'île de Bakassi.

Sourna Loumtouang, E (2014) "Les frontières dans le lac Tchad : une notion ignorée ou contestée?" 4(1) History Rewiew of the University of Sherbrooke 1-18.

63 Following Article 5 of the Treaty on the Conservation and Sustainable Management of Forest Ecosystems in Central Africa and Establishing the Central African Forest Commission adopted in 2005 in Brazzaville. 